Miller et al.: Variability in the Mobilization of Sediment and P across 13 Soils

\title{
Variability in the Mobilization of Sediment and Phosphorus across 13 European Soils
}

Nicola Miller, John N. Quinton, ${ }^{*}$ Elisabetta Barberis, and Manuela Presta

N. Miller, Natl. Soil Resources Inst., Cranfield Univ., Cranfield, MK43 0AL, UK; J.N. Quinton, Lancaster Environ. Centre, Lancaster Univ., Lancaster LA1 4YQ, UK; E. Barberis and M. Presta, Di. Va. P.R.A.- Chimica Agraria, Univ. of Torino, Via Leonardo da Vinci, 44, 10095 Grugliasco, Torino, Italy. Received 25 Jan. 2008.*Corresponding author(J.Quinton@Lancaster.ac.uk).

\begin{abstract}
The objectives of this study were to examine the variability in mobilization and transport of primary particles and associated total phosphorus (TP) in sediments eroded by overland flow from 13 European arable soils and to consider the empirical support for more process-based alternatives to modeling phosphorus (P) transfers. The 13 soils were subjected to simulated rainfall in laboratory experiments. Rainfall was applied to a soil flume $(0.5 \times 0.25 \mathrm{~m})$ for $30 \mathrm{~min}$ at intensity of $60 \mathrm{~mm} \mathrm{~h}^{-1}$, and all overland flow generated during this period was collected. Two simulations were performed $5 \mathrm{~d}$ apart. The soils generated a wide range of overland flow (13.3$26.9 \mathrm{~mm}$ ) and sediment (1.1-16.9 g). The sediments from the experiments were enriched with medium silt particles $(6-20 \mu \mathrm{m})$. Except for one soil in the second simulation, all of the study soils produced overland flow sediments (OFS) that were enriched with P (TP 976-3884 mg kg $\mathrm{g}^{-1}, \mathrm{P}$ enrichment ratio 0.92-4.42). Sediment TP was positively correlated $(P<0.05)$ with the sediment clay contents for both simulation events, and sediment total $P$ enrichment was negatively correlated with soil TP. Attempts to reconstruct the TP content of sediments from TP analysis of the soil particle size fractions yielded significant $(P<0.05)$ relationships between reconstructed and measured TP values. However, the reconstructed TP values were consistently lower than the measured sediment TP contents, indicating that further improvements to measurement techniques are required if physically based modeling of $P$ transport in overland flow is to be successful at small scales.
\end{abstract}

Abbreviations: ESR, exchangeable sodium ratio; MUSLE, Modified Universal Soil Loss Equation; OFS, overland flow sediments; P, phosphorus; SWAT, Soil and Water Assessment Tool; TP, total phosphorus.

PHOSPHORUS and sediment play a major role in reducing the quality of freshwater. Phosphorus is a key element in controlling eutrophication (European Environment Agency, 1999), and in recent years there have been costly reductions in point source $P$ loads from wastewater treatment works, with the aim of improving water quality (Withers et al., 2000). Sediment in waters leads to low light penetration and the siltation of salmonid spawning grounds and is important for transporting contaminants (Quinton and Catt, 2007). While efforts to reduce the losses of P and sediment from soils to waters have been underway for a number of years, recent reviews of the contribution of agriculture to the pollution of United Kingdom and European rivers suggest that it is contributing approximately one-third of all P (de Wit et al., 2002; White and Hammond, 2006). By contrast, in the United States, Carpenter et al. (1998) estimated that $84 \%$ of all $\mathrm{P}$ discharged to surface waters is from nonpoint sources.

The recognition of sediment and $\mathrm{P}$ as major contributors to water quality has led to the development of a number of water quality models with the objective of predicting the transport of P from soils to waters. Such models include Opus (Smith, 1992) and Soil and Water Assessment Tool (SWAT; Chaubey et al., 2006). These models have relied on semi-empirical relationships to describe P loss. Soil and Water Assessment Tool uses the Modified Universal Soil Loss Equation (MUSLE) model (Williams et al., 1984) to produce sediment yield, which is then converted to a P loss 
by using a relationship between sediment concentration and enrichment ratio from Menzel (1980). Opus uses a more physically based approach to sediment generation and the interaction between sediment and $\mathrm{P}$, but it still relies on an enrichment ratio to calculate the P loading.

Enrichment ratios for sediment and $\mathrm{P}$ are therefore critical to the prediction of pollutant transport; however, they are dependent on a number of processes which are interacting across time and space. At a landscape scale, these processes are likely to be occurring simultaneously, and different processes will dominate depending on the landscape position and the antecedent condition at that point in the landscape. In overland flow, sediment and particulate $\mathrm{P}$ can be mobilized by rain splash detachment, flow detachment, or dispersion. Particles are transported by rain splash and overland flow. Travel distances are typically in the order of centimeters for splashed particles (Poesen, 1985). In overland flow, particle transport is dependent on the particle settling velocity and the hydraulic properties of the flow, but, in general, small particles travel farther than large ones. Dissolved P is mobilized by direct loss of the soil solution or by desorption from sediment (including organic matter) or soil surfaces. Note that it is quite possible for sediment to adsorb $\mathrm{P}$ from the solution during transport in overland flow (McDowell et al., 2001).

There is disagreement in the literature regarding the specific size of soil particles that are preferentially detached by rain splash and transported by overland flow. Gabriels and Moldenhauer (1978) found that, at equilibrium, rain-splashed sediments were not different from their parent soils. Other studies have reported that particles $<53 \mu \mathrm{m}$ (Ghadiri and Rose, 1991), <63 $\mu \mathrm{m}$ (Sutherland et al., 1996), $<105 \mu \mathrm{m}$ (Ellison, 1944), and between 110 and $1450 \mu \mathrm{m}$ (Farmer, 1973) were preferentially detached by rain splash. Rainfall characteristics and soil type are both likely to affect the selectivity of rain splash and overland flow, and the variation between these studies probably results from differences in experimental conditions such as soil type, raindrop size, rainfall intensity, and kinetic energy. Detachment by dispersion is a process that has been overlooked in the soil erosion literature. It is affected by a number of soil properties such as texture, mineralogy (Levy et al., 1993), exchangeable sodium ratio (ESR; Levy et al., 1993; Shainberg et al., 1992), and surface charge of soil particles (Lima et al., 2000) and is particularly high in soils rich in clay, with high ESR, and particles saturated with anions, such as phosphate. Thus, particles released to overland flow by this mechanism are likely to be in the colloidal fraction.

Given that fine particles have a large specific surface area and capacity to absorb $\mathrm{P}$ (Wild, 1988), $\mathrm{P}$ enrichment of eroded sediments is often a consequence when particles are selectively detached and transported. As is the case for splash-detached sediment, there is a wide range of enrichment ratios reported for flow-transported P. Sharpley (1985) measured the enrichment of TP in OFS from six soils using small soil flumes (similar to those used in this study). He reported enrichment ratios for TP of 1.3 to 1.7 , which were significantly positively correlated with the clay enrichment ratios of 1.3 to 1.9. Other researchers have found $P$ enrichment ratios from zero to values greater than six (Massey and Jackson, 1952; Sharpley, 1980; Sharpley, 1985). This variability is likely to be a function of a number of parameters. There has been limited work on this outside of Sharpley's (1980) simulated rainfall study, which concluded that the fundamental soil physical and chemical properties of five soils had little effect on the enrichment ratios of $\mathrm{P}$ and that energy of rainfall and overland flow and soil $\mathrm{P}$ status were more important in influencing $\mathrm{P}$ enrichment. In this paper, we 
test this finding by examining the variability in $\mathrm{P}$ detachment and transport by splash and shallow rain-impacted flow from a wide range of soils and consider the empirical support for a more process-based alternative to current $\mathrm{P}$ modeling approaches.

\section{MATERIALS AND METHODS}

\section{Study Soils}

Soils with contrasting physicochemical properties and management histories were collected from 13 arable sites in five European countries (Table 1); these represent a subset of the soils described in Withers et al. (2007). The soils represented five textural groups classified by the USDA system. In management terms, the soils had received a variety of $\mathrm{P}$ fertilization. The soils were collected from 0 to $10-\mathrm{cm}$ depths and air-dried before being passed through a 5-mm sieve.

\section{Rainfall Simulations}

Small flume experiments were undertaken to determine the detachment and transport of sediment and P from the 13 study soils. The flumes allowed good control of the initial conditions, with the objective of removing variability caused by factors other than those influenced by soil properties. As the study was focused on understanding process rather than soil management, this was considered to be a reasonable approach. Three replicated small soil flumes were prepared for each soil. Aliquots of the air-dried, sieved soils were packed into metal trays $(0.5 \times 0.25 \times 0.085$ m; Fig. 1) to a bulk density of $1.3 \mathrm{~g} \mathrm{~cm}^{-3}$. The trays had perforated bases to allow drainage and were fitted with an outlet tube at one end, at the height of the soil surface, to allow the collection of overland flow. Once the trays were packed, the soil was wetted by capillary rise for $24 \mathrm{~h}$ and allowed to drain for a further $24 \mathrm{~h}$ before rainfall was applied. Before and after each rainfall event, moisture content was measured at three random points in the soil, using a theta probe (Delta-T devices, Cambridge, UK).

A 9-m gravity-fed rainfall simulator was used to produce rainfall. To ensure the water chemistry was consistent throughout the series of experiments, deionized water was fed through the simulator. Raindrops were formed as water passed through hypodermic needles embedded in a tray $9 \mathrm{~m}$ above the soil surface. The falling raindrops passed through a mesh screen that produced a random drop size distribution. The median drop size of the rainfall was $1.03 \mathrm{~mm}$. The soil trays were placed under the rainfall on a $5^{\circ}$ slope and rainfall was applied at $60 \mathrm{~mm} \mathrm{~h}^{-1}$ for $30 \mathrm{~min}$. Overland flow was collected for three periods: 0 to 10,10 to 20 , and 20 to $30 \mathrm{~min}$ after rainfall began. For each time period, the volume of overland flow was measured and a subsample taken for gravimetric determination of the sediment concentration (Bartram and Ballance, 1996). After the initial rainfall event (Event 1), the soil trays were left for $5 \mathrm{~d}$ and the simulated rainfall experiment was repeated (Event 2).

\section{Phosphorus Analyses}

Soil TP was determined by inductively coupled plasma-optical emission spectroscopy (ICP-OES) after digestion with concentrated sulfuric and perchloric acid (Sparks et al., 1996).

The overland flow samples were stored at $5^{\circ} \mathrm{C}$ in polyethylene bottles that had previously been rinsed in 5\% $\mathrm{HCl}$ and deionized water. First, each sample was digested using sulfuric acid-persulfate digestion adapted from Eisenreich et al. (1975) 
and described by Rowland and Haygarth (1997). The concentration of TP was determined colormetrically using the method of Murphy and Riley (1962). Samples were analyzed as soon as possible after collection and always within $14 \mathrm{~d}$. Total load of TP produced during the $30 \mathrm{~min}$ rainfall event was calculated as the sum of the product of volume of overland flow TP concentration for each sampling interval of the rainfall simulation experiments. The enrichment ratio (ER) for the OFS TP was defined as the ratio of the OFS TP content to the original soil content.

\section{Particle Size Analyses}

To collect sufficient overland flow sediment from rainfall simulation experiments for particle size analysis, it was necessary to bulk together the sediment from the three replicates. For each soil, $10 \mathrm{~g}$ of sieved $(2 \mathrm{~mm})$ soil was treated with $30 \% \mathrm{H}_{2} \mathrm{O}_{2}$ to destroy soil organic matter and then dispersed with $\mathrm{Na}_{4} \mathrm{P}_{2} 0_{7}$; these steps were not performed for the OFS. Soil and sediment samples were passed through a $125 \mu \mathrm{m}$ sieve before being analyzing for particle size with a Sedigraph 5100 (MicroMetrics, Londonderry, USA). For the Sedigraph analyses, $3 \mathrm{~g}$ of soil or sediment plus $75 \mathrm{~mL}$ of deionized water were left to stand overnight. One milliliter of sodium hydroxide $0.01 \mathrm{~mol} \mathrm{~L}^{-1}$ was added as a dispersant and the samples were shaken for $1 \mathrm{~h}$ before being analyzed. Sodium hydroxide was used, rather than the more normal sodium hexametaphosphate dispersant, to avoid contaminating the sediment samples, needed for TP analysis, with $\mathrm{P}$.

\section{Analysis of TP Content of Particle Size Fractions}

To analyze the TP content of the silt and clay fractions, $5 \mathrm{~g}$ of soil was weighed into $500 \mathrm{~mL}$ centrifuge bottles to which $500 \mathrm{~mL}$ of $1 \mathrm{mmol} \mathrm{L}^{-1} \mathrm{NaCl}$ was added. The bottles were shaken in a horizontal shaker for $240 \mathrm{~min}$ at $160 \mathrm{rpm}$ and then transferred to a measuring cylinder, which was inverted five times before placing on a firm bench. Aliquots of the $<63 \mu \mathrm{m},<20 \mu \mathrm{m}$, and $<6.3 \mu \mathrm{m}$ fractions were collected after allowing the suspension to sediment for $1 \mathrm{~min} 20 \mathrm{sec}, 12 \mathrm{~min}$, and $2 \mathrm{~h}$, respectively. The suspensions were then centrifuged at $500 \mathrm{rpm}$ for $6 \mathrm{~h} 45 \mathrm{~min}$ so that the $<2 \mu \mathrm{m}$ particles were kept in suspension and aliquots were collected. For each of the suspensions, suspended sediment concentration was determined gravimetrically (Bartram and Ballance, 1996). Total P was determined colormetrically, using the method of Murphy and Riley (1962), after digesting the dry residue with aqua-regia. To ensure that the results from the aqua-regia method were comparable with those from the sulfuric acid-persulfate method, used for digesting the soils and OFS, the samples in the $<0.63 \mu \mathrm{m}$ size range were digested using both methods and good agreement for TP $(r=0.98 ; P<0.01)$ was found. We are therefore confident that the results from the two digestion methods used in this study are comparable. Total $P$ contents of the fine, medium, and coarse silt fractions $(2-6.3 \mu \mathrm{m}, 6.3-20 \mu \mathrm{m}$, and 20$63 \mu \mathrm{m})$ were found by subtracting the TP content of the smaller size fraction from the TP content of the larger size fraction (i.e., for the $2-6.3 \mu \mathrm{m}$ size range the TP content of the $<2 \mu \mathrm{m}$ fraction was subtracted from the TP content of the $<6.3 \mu \mathrm{m}$ fraction). Phosphorus enrichment ratios were calculated as the ratio of the TP content of the size fraction to the TP content of the bulk soil.

\section{Reconstruction of Sediment TP Concentration}

Total P contents for the 20 to $63 \mu \mathrm{m}, 6.3$ to $20 \mu \mathrm{m}, 2$ to $6.3 \mu \mathrm{m}$, and $<2 \mu \mathrm{m}$ fractions of the 13 soils were determined using the TP concentration and respective 
size fraction concentrations from the particle size fraction data. This was then combined with the appropriate proportion of overland flow sediment in each particle size fraction to give the TP content of each size fraction of the overland flow sediment. These values were then summed and compared to the TP content obtained for the bulk overland flow sediment sample.

\section{Statistical Analyses}

All statistical analyses were performed using Statistica (v. 6.0; StatSoft, Inc., 1984-2003, Tulsa, USA). The results of the three time intervals were averaged to give a single result for each 30-min rainfall event. The chi-square test was used to compare the particle size distributions of soils and OFS. Analysis of variance was performed to compare the TP contents of the soil and the OFS.

\section{RESULTS}

\section{Soil Properties}

The texture of the study soils ranged from silty clay (Turku) to a sandy loam (Gleadthorpe; Table 1). Ten of the soils had high silt contents (57-76\%) and were classified as either silt loam or loam; however, particle size analysis showed that the contribution of coarse, medium, and fine silt to the total silt content varied widely among the soils (Table 1).

\section{Total P Content of Particle Size Fractions}

Apart from the Gleadthorpe soil, no P enrichment of the silt fraction was found for the studied soils (Table 2), with the highest concentrations of TP located in the clay fraction. These ranged between 1428 and $4732 \mathrm{mg} \mathrm{kg}^{-1}$ and were between 1.21 and 7.26 times that of the parent soil. Phosphorus concentrations in the silt fraction were typically lower, ranging from 286 to $1688 \mathrm{mg} \mathrm{kg}^{-1}$, with $\mathrm{P}$ enrichment ratios ranging from 0.24 to 1.92 .

\section{Overland Flow and Sediment Loss}

The volume of overland flow produced from the 13 soils during the $30-\mathrm{min}$ rainfall events varied significantly $(P<0.01)$. The total volume of overland flow produced from the 13 soils during Events 1 and 2 (Table 3 ) was not significantly different $(P>0.05)$, with means of 21.8 and $22.4 \mathrm{~mm}$ and a range of 13.6 and 10.8 $\mathrm{mm}$, respectively. The total sediment load generated from the 13 soils varied significantly $(P<0.01)$; however, there was no significant difference $(P>0.05)$ between the loads produced during Events 1 and 2 . The total sediment load of overland flow generated from the 13 soils ranged from 1.7 and $1.1 \mathrm{~g}$ to 16.9 and $16 \mathrm{~g}$ in Event 1 and Event 2, respectively, with a mean of $4.4 \mathrm{~g}$ for Event 1 and $3.7 \mathrm{~g}$ for Event 2.

\section{Particle Size Distribution of Soil and Overland Flow Sediment}

With the exception of the soils from Turku and Tetto Frati in Event 1 and the soils from Bonavia, Ritzelhof 4, Sale, Turku, and Tetto Frati in Event 2, there were significant differences $(P<0.05)$ between the particle size distribution of the overland flow sediment and that of the original soil. For 12 of the study soils, no significant difference was found between the particle size distribution of the OFS produced from Events 1 and 2; however, the particle size distribution of the sediment eroded from the 
Gleadthorpe soil was significantly different in Event 1 and Event $2(P<0.05)$, with higher sand and lower fine silt content in the sediment eroded in Event 2.

Overall, OFS generated during Events 1 and 2 tended to contain less sand than the soil, but with no clear pattern for silt and clay contents (Fig. 2). The Gleadthorpe soil stands out due to the much larger amounts of silt and clay lost relative to the original soil. Figure 3 allows us to look in more detail at the shifts in the enrichment of the silt fraction. It is apparent for both Events 1 and 2 that most soils behave in a similar way, with the medium silt content increasing from the soil to the sediment at the expense of the coarse silt, but with little change in the fine silt content of the sediment when compared to the soil.

\section{Enrichment of Phosphorus in Overland Flow Sediments}

The TP content of the OFS from the study soils ranged from 1027 to $2884 \mathrm{mg}$ $\mathrm{kg}^{-1}$ (mean of $1700 \mathrm{mg} \mathrm{kg}^{-1}$ ) in Event 1, and from 976 to $3884 \mathrm{mg} \mathrm{kg}^{-1}$ (mean of $1906 \mathrm{mg} \mathrm{kg}^{-1}$ ) in Event 2 (Table 3). For all of the study soils, there was no significant difference $(P>0.05)$ between the TP content of the OFS from Events 1 and 2. There was significantly higher TP in the OFS than in the original soil $(P<0.01)$. The ranges of TP contents in the OFS from the 13 soils were greater $\left(1857\right.$ and $2908 \mathrm{mg} \mathrm{kg}^{-1}$ for Event 1 and 2, respectively) than the range of TP contents in the original soil (1464 $\mathrm{mg} \mathrm{kg}^{-1}$ ). There was no correlation between the TP content of OFS and the volume of overland flow or total sediment load of the rainfall event for the 13 soils.

There was no significant $(P<0.05)$ relationship between the TP content of the original soils and OFS (Table 3 ). However, sediment TP enrichment ratios increased as the soil TP content decreased (Event 1: $r=0.53, P<0.05$; Event 2: $r=0.64, P<$ 0.05; Fig. $4 \mathrm{a}$ and b). The Turku soil had the highest TP content of the soils (1868 $\mathrm{mg}$ $\mathrm{kg}^{-1}$ ) and had one of the lowest enrichment ratios for TP in the OFS (1.1 and 1.24 for Events 1 and 2, respectively), while the Keszthely soil had the lowest soil TP content (404 mg kg${ }^{-1}$ ) and had one of the highest TP enrichment ratios in the OFS (3.16 and 3.39 for Events 1 and 2, respectively).

\section{Relationship between Primary Particle and TP Enrichment in Overland Flow Sediments}

Total P enrichment was positively correlated with sediment clay content for both events (Event 1: $r=0.63, P<0.05$; Event 2: $r=0.62, P<0.05$ ) and negatively correlated with the OFS fine sand content for Event $2(r=-0.65, P<0.05)$. The Turku, Bonavia, Ritzelhof 4, Sale, and Tetto Frati soils produced OFS that were not significantly different from the original soil in terms of particle size distribution, and three of these soils (Turku, Bonavia, and Tetto Frati) had the lowest enrichment of TP, ranging from 1.08 to 1.17 in Event 1 and from 0.92 to 1.29 in Event 2. Overland flow sediments from the Keszthely and Gleadthorpe soils had the highest TP enrichment ratios (Event 1: 3.16 and 3.28, Event 2: 3.39 and 4.42, respectively) of the study soils and this was reflected in the enrichment of medium and fine silt fractions in these OFS, which for Gleadthorpe was higher than for any other soil in Event 1 (enrichment ratios of 2.61 and 4.42 for medium and fine silt, respectively). However, enrichment of silt and clay fractions did not always result in P enrichment - the Villafranca Piemonte had the second highest enrichment of the fine silt fraction (3.96 and 2.76 in Events 1 and 2, respectively) yet produced lower TP enrichment ratios (1.65 and 1.55 in Events 1 and 2, respectively). 


\section{Reconstruction of Overland Flow Sediment TP concentration}

There was a significant (Event 1: $r=0.72, P<0.01$; Event 2: $r=0.77, P<0.01$ ) linear relationship between the reconstructed values for the concentration of $P$ in the OFS and the bulk sediment TP analysis (Fig. 5) for Events 1 and 2. However, the reconstructed TP contents were almost always lower than those determined for the bulk OFS.

\section{DISCUSSION}

\section{Particle Size Distribution of Overland flow Sediments}

Given the small scale of the experiments and the shallow $(<5 \mathrm{~mm})$ flow depths generated during the experiments, we would expect that the OFS would be dominated by fine particles with low settling velocities. Although our results do show enrichment of the sediment silt fraction, supporting those of Alberts et al. (1980), Ellison (1944), Ghadiri and Rose (1991), Wan and El-Swaify (1997), they do not show enrichment across all silt and clay sized material. The amount of particle enrichment also varies between soils and this is likely to be due to the way that aggregates from the different soils fragment when struck by raindrops and the fate of these fragments as they are transported in overland flow.

Raindrops impacting on a soil surface may fragment aggregates and dislodge primary particles, either by physical detachment or physio-chemical dispersion. Both sets of particles may be entrained by overland flow and the aggregate fragments may be fragmented further during transportation, by rolling or saltating along the soil surface, colliding with other aggregates in the flow, or by being struck by additional raindrops. It is therefore likely that what we are measuring is the particle size distribution of a mix of aggregates and primary particles. We can hypothesize that in soils such as Turku, for which the OFS was similar in composition to the parent, the primary mechanism for particle transport was as discrete aggregates - the aggregates were detached from the soil surface, but did not break down to primary particles during transport, and were not, therefore, exposed to selective transport mechanisms, such as those described by Hairsine and Rose (1992). Unstable soils, such as Gleadthorpe, where the OFS had a very different composition to the soil, are likely to have been broken down to primary particles, which were then subjected to selective transport by the shallow rain-impacted overland flow generated in these experiments, resulting in a much finer overland flow sediment than the parent soil. For many of the soils which were not at these two extremes, it is likely that there was a mix of aggregate and primary particle transport.

The hypothesis that there is a combination of aggregate and particle transport operating in parallel is further corroborated if we consider that the clay fraction was only enriched in the OFS from five of the soils. This result is surprising when the findings of previous research are considered. Clay enrichment of OFS has been reported in studies at a range of scales (Alberts et al., 1980; Quinton et al., 2001; Sharpley, 1985). Clay enrichment occurs because, once in suspension, clay particles can be transported longer distances downslope than coarser particles by low energy flow (Alberts et al., 1980; Gabriels and Moldenhauer, 1978). Gabriels and Moldenhauer (1978) reported that the amount of clay in rain-splashed sediments was two to four times lower than in OFS. In the present study, the cohesiveness of clay particles may have prevented their detachment by rain splash, limiting the clay 
particles available for transport by overland flow to those that were transported incorporated within aggregates.

\section{Phosphorus Enrichment of Overland Flow Sediments}

Overland flow sediments from all but one of the study soils were enriched with TP when compared with the soil from which they were derived. Numerous other researchers have reported $\mathrm{P}$ enrichment of OFS in erosion experiments at a range of scales (Kronvang, 1990; Massey and Jackson, 1952; Quinton et al., 2001; Sharpley, 1985; Sholtenberg and While, 1953). The extent to which OFS were enriched with TP varied between soils, and, as expected, the TP content of the OFS was not correlated to the TP content of the soils. Previous research has shown that TP enrichment of OFS decreases as the amount of erosion increases (Quinton et al., 2001; Sharpley, 1980; Sharpley, 1985). No such relationship was found when the TP content of OFS was compared to the total sediment load for the 13 study soils, probably because the effect of soil type on the TP content of OFS was more dominant.

Our results corroborate the findings of Quinton et al. (2001), Sharpley, (1980), and Sharpley (1985) that the presence of P-rich clay particles contributes to the $\mathrm{P}$ enrichment of OFS, although - as Sharpley (1985) concluded from indoor rainfall simulator experiments - clay enrichment alone could not fully explain the $\mathrm{P}$ enrichment of OFS. It is likely that organic $\mathrm{P}$ would have been an important constituent of our OFS, as organic P contents accounted for 9 to $25 \%$ of the soil TP (H. Hartikainen, personal communication, 2008). Some of the P containing organic matter is likely to have been associated with the colloidal fraction (Lagaly, 1984) and to have been included in determination of the sediment's clay fraction. However, the contribution to the TP content of the OFS by other more buoyant material has not been accounted for and might have helped to explain more fully the $\mathrm{P}$ enrichment of the OFS.

\section{Reconstruction of Overland Flow Sediment TP Concentration}

The consistent underestimation of the OFS TP concentration using the TP concentrations of the particle size fractions is not surprising. We lacked TP values for the sand fraction, and although TP concentrations in the sand fraction are likely to be smaller that the silt and clay fractions their TP content can still be significant (e.g., Maguire et al., 1998). Organic P may also be underrepresented in our analysis: although we analyzed for Total $\mathrm{P}$, which will have included most organic material, it is possible that some buoyant organic matter might have been missed during the particle size separation. It is also possible that the $<2 \mu \mathrm{m}$ size fraction is not strictly comparable for the size separation and OFS particle size analysis. Although both procedures were based on sedimentation, using $\mathrm{NaOH}$ as a dispersant, the size separation relied on centrifugation followed by pipette sampling to obtain the $<2 \mu \mathrm{m}$ fraction, compared to sedimentation and in situ analysis used by the sedigraph. As the highest concentrations of TP reside in the clay fraction, small discrepancies between the methods may lead to relatively larger differences in TP content.

These findings have important implications for those developing size selective models of P mobilization and transfer. Particle size selective models of erosion processes have been introduced at the depositional stage of erosion models (Hairsine and Rose, 1992; Smith, 1992; Smith et al., 1995; Charpin and Myers, 2005). Smith (1992) also incorporated P concentrations in the predictions made by Opus, and Charpin and Myers (2005) included the potential for selective detachment and 
transport into their model of selective transport in overland flow. Although these models provide conceptually advanced descriptions of selective erosion processes, their ability to predict the transport of $\mathrm{P}$ associated with soil particles is limited by our ability to describe the soil environment. Even at this scale, where we had good control over our experiments, we could not reconstruct the TP content of the OFS from the P concentration by particle size distribution with complete confidence. This implies that we cannot accurately measure the parameters that our model process descriptions demand - in this case the P distribution by particle size — or that we have missed something in our process description and we are therefore not measuring it (e.g., organic forms of $\mathrm{P}$ ) or that we are not capturing the natural variation of soil properties with our measurements. Simulation results from such models are therefore likely to be in error until we can improve our measurement techniques.

\section{CONCLUSIONS}

Our study confirms that soil type plays a major role in determining the size of particles that are preferentially detached and transported by rain splash and overland flow. Medium silt particles $(6-20 \mu \mathrm{m})$ were enriched more than other size fractions. While this is partly a function of a lower settling velocity than larger silt and sand particles, we believe that at this scale it is also due to the cohesive nature of particles $<2 \mu \mathrm{m}$, which resisted detachment and were transported primarily as aggregates.

The enrichment of TP in OFS occurred from a wide range of soils. The selective transport of fine particles $(<20 \mu \mathrm{m})$ appears to be the primary cause. By using the TP content of different particle sizes it was possible to reconstruct the TP content of the OFS, with a limited degree of confidence, suggesting that if measurement methods can be improved, process-based descriptions of selective erosion processes have the potential to predict $\mathrm{P}$ transfer in overland flow at a small scale.

\section{ACKNOWLEDGMENTS}

This work was funded by the European Union (EVK1-CT-1999-00007). The authors gratefully acknowledge H. Hartikainen, P. Strauss, and P. Withers for their contributions; K. Ritz and J. Rickson for useful discussions; and C. Watts for the use of Sedigraph.

\section{REFERENCES}

Alberts, E.E., W.C. Moldenhauer, and G.R. Foster. 1980. Soil aggregates and primary particles transported in rill and interrill flow. Soil Sci. Soc. Am. J. 44:590-595.

Bartram, J., and R. Ballance. 1996. Water quality monitoring: A practical guide to the design and implementation of freshwater quality studies and monitoring programmes. E \& FN Spon, London.

Carpenter, S.R., N.F. Caraco, D.L. Correll, R.W. Howarth, A.N. Sharpley, and V.H. Smith. 1998. Nonpoint pollution of surface waters with phosphorus and nitrogen. Ecol. Appl. 8:559-568.

Charpin, J.P.F., and T.G. Myers. 2005. Modelling thin film flow with erosion and deposition. Adv. Water Resour. 28:761-772.

Chaubey, I., K.W. Migliaccio, C.H. Green, J.G. Arnold, and R. Srinivasan. 2006. Phosphorus modeling in Soil and Water Assessment Tool (SWAT) Model. p. 163-188. In D.E. Radcliffe and M.L. Cabrera (ed.) Modeling phosphorus in the environment. CRC Press, Boca Raton, FL. 
de Wit, M., H. Behrendt, G. Bendoricchio, W. Bleuten, and P. van Gaans. 2002. The contribution of agriculture to nutrient pollution in three European rivers, with reference to the European Nitrates Directive., p. 19 Eur. Water Management Online. Eur. Water Association, Hennef, Germany.

Eisenreich, S.J., R.T. Bannerman, and D.E. Armstrong. 1975. Simplified phosphorus analysis technique. Environ. Lett. 9:43-53.

Ellison, W.D. 1944. Studies of raindrop erosion. Agric. Eng. 25:131-136.

European Environment Agency. 1999. Lakes and reservoirs in the EEA area. Topic Report 1. European Environment Agency, Copenhagen, Denmark.

Farmer, E.E. 1973. Relative detachability of soil particles by simulated rainfall. Soil Sci. Soc. Am. Proc. 37:629-633.

Gabriels, D., and W.C. Moldenhauer. 1978. Size distribution of eroded material from simulated rainfall: Effect over a range of textures. Soil Sci. Soc. Am. J. 42:954958.

Ghadiri, H., and C.W. Rose. 1991. Sorbed chemical transport in overland flow: I. A nutrient and pesticide enrichment mechanism. J. Environ. Qual. 20:628-633.

Hairsine, P.B., and C.W. Rose. 1992. Modeling water erosion due to overland flow using physical principles: I. Uniform flow. Water Resour. Res. 28:237-243.

Kronvang, B. 1990. Sediment-associated phosphorus transport from two intensively farmed catchment areas. p. 311-330. In J. Boardman (ed.) Soil erosion on agricultural land. John Wiley \& Sons, Chichester, UK.

Lagaly, G. 1984. Clay-organic interactions. Philos. Trans. R. Soc. London A. 311:315-332.

Levy, G.J., H. Eisenberg, and I. Shainberg. 1993. Clay dispersion as related to soil properties and water permeability. Soil Sci. 155:15-22.

Lima, J.M., S.J. Anderson, and N. Curi. 2000. Phosphate-induced clay dispersion as related to aggregate size and composition in Hapludoxs. Soil Sci. Soc. Am. J. 64:892-897.

Maguire, R. O., A. C. Edward, and M. J. Wilson. 1998. Influence of cultivation on the distribution of phosphorus in three soils from NE Scotland and their aggregate size fractions. Soil Use Manage. 14:147-153.

Massey, H.F., and M.L. Jackson. 1952. Selective erosion of soil fertility constituents. Soil Sci. Soc. Am. Proc. 16:353-356.

McDowell, R., A. Sharpley, and G. Folmar. 2001. Phosphorus export from an agricultural watershed: Linking source and transport mechanisms. J. Environ. Qual. 30:1587-1595.

Menzel, R. 1980. Enrichment ratios for water quality modeling. p. 486-492. In W.G. Knisel (ed.) CREAMS: A field-scale model for chemicals, runoff, and erosion from agricultural management systems. USDA Conservation Research Report Number 26. USDA, Washington, DC.

Murphy, J., and J.P. Riley. 1962. A modified single solution method for determination of phosphate in natural waters. Anal. Chim. Acta 27:31-36.

Poesen, J. 1985. An improved splash transport model. Z. Geomorphol. 29:193-211. 
Quinton, J.N., and J.A. Catt. 2007. Soil erosion and metal transport from agricultural fields. Environ. Sci. Technol. 41:3495-3500.

Quinton, J.N., J.A. Catt, and T.M. Hess. 2001. The selective removal of phosphorus from soil: Is event size important? J. Environ. Qual. 30:538-545.

Rowland, A.P., and P.M. Haygarth. 1997. Determination of total dissolved phosphorus in soil solutions. J. Environ. Qual. 26:410-415.

Shainberg, I., D. Warrington, and J.M. Laflen. 1992. Soil dispersibility, rain properties, and slope interaction in rill formation and erosion. Soil Sci. Soc. Am. J. $56: 278-283$.

Sharpley, A.N. 1980. The enrichment of soil phosphorus in runoff sediments. J. Environ. Qual. 9:521-526.

Sharpley, A.N. 1985. Depth of surface soil-runofff interaction as affected by rainfall, soil slope, and managment. Soil Sci. Soc. Am. J. 49:1010-1015.

Sholtenberg, N.L., and J.L. While. 1953. Selective loss of plant nutrients by erosion. Soil Sci. Soc. Am. Proc. 29:209-213.

Smith, R.E. 1992. Opus, an integrated simulation model for transport of nonpoint source pollutants at the field scale: Volume I, Documentation. ARS-98. USDA Agricultural Research Service, Washington, DC.

Smith, R.E., D.C. Goodrich, and J.N. Quinton. 1995. Dynamic, distributed simulation of watershed erosion- the Kineros2 and Eurosem Models. J. Soil Water Conserv. 50:517-520.

Sparks, D.L., A.L. Page, P.A. Helmke, R.H. Loeppert, P.N. Soltanpour, M.A. Tabatabai, C.T. Johnston, and M.E. Summer. 1996. Methods of soil analysis, parts 2 and 3. Chemical analysis. Soil Science Society of America, Madison, WI.

Sutherland, R.A., Y. Wan, C.-T. Lee, and A.D. Ziegler. 1996. Aggregate enrichment ratios for splash and wash transported sediment from an Oxisol. Catena 26:187208.

Wan, Y., and S.A. El-Swaify. 1997. Flow-induced transport and enrichment of erosional sediment from a well-aggregated and uniformly-textured Oxisol. Geoderma 75:251-265.

White, P.J., and J.P. Hammond. 2006. Updating the estimates of the sources of phosphorus in UK waters. Defra, London.

Wild, A. 1988. Plant nutrients in soil: Phosphate. p. 695-743. In A. Wild (ed.) Russell's soil conditions and plant growth. Longman Scientific and Technical, Harlow, UK.

Williams, J.R., C.A. Jones, and P.T. Dyke. 1984. Modelling approach to determining the relationship between erosion and soil productivity. Trans. ASAE 27:129-144.

Withers, P.J.A., I.A. Davidson, and R.H. Foy. 2000. Prospects for controlling nonpoint phosphorus loss to water: A UK perspective. J. Environ. Qual. 29:167175.

Withers, P.J.A., R.A. Hodgkinson, E. Barberis, M. Presta, H. Hartikainen, J.N. Quinton, N. Miller, I. Sisak, P. Strauss, A. Mentler, and E. Azozglu. 2007. An environmental soil test to determine the intrinsic risk of sediment and phosphorus mobilisation from European soils. Soil Use Manage. 23:57-70. 
Table 1. Soil textural classification, particle size distribution, organic matter, and total phosphorus (TP) content of 13 study soils.

\begin{tabular}{|c|c|c|c|c|c|c|c|c|c|}
\hline & & & & & Particle & size analys & S $(\%)$ & & \\
\hline Site & Country & $\begin{array}{c}\text { USDA } \\
\text { classification }\end{array}$ & $\begin{array}{c}\text { Textural } \\
\text { classification }\end{array}$ & Sand & $\begin{array}{l}\text { Coarse } \\
\text { silt }\end{array}$ & $\begin{array}{l}\text { Medium } \\
\text { silt }\end{array}$ & $\begin{array}{l}\text { Fine } \\
\text { silt }\end{array}$ & Clay & $\begin{array}{r}\text { Orga } \\
\text { mat }\end{array}$ \\
\hline & & & & $\begin{array}{l}>61 \\
\mu \mathrm{m}\end{array}$ & $\begin{array}{c}20-61 \\
\mu \mathrm{m}\end{array}$ & 6-20 $\mu \mathrm{m}$ & $\begin{array}{l}2-6 \\
\mu \mathrm{m}\end{array}$ & $\begin{array}{l}0.54- \\
2 \mu \mathrm{m}\end{array}$ & \\
\hline Rosemaund & $\mathbf{U K}$ & $\begin{array}{l}\text { Oxyaquic } \\
\text { Hapludalfs }\end{array}$ & Silt loam & 9 & 27 & 27 & 12 & 25 & 3.7 \\
\hline Gleadthorpe & UK & $\begin{array}{l}\text { Typic } \\
\text { Udipsamments }\end{array}$ & Sandy loam & 65 & 15 & 7 & 3 & 10 & 2.0 \\
\hline Olcenengo & Italy & $\begin{array}{l}\text { Typic } \\
\text { Udipsamments }\end{array}$ & Silt loam & 27 & 34 & 16 & 5 & 18 & 2.3 \\
\hline $\begin{array}{l}\text { Villafranca } \\
\text { Piemonte }\end{array}$ & Italy & $\begin{array}{l}\text { Oxyaquic } \\
\text { Ustifluvents }\end{array}$ & Loam & 41 & 22 & 18 & 6 & 13 & 1.7 \\
\hline Bonavia & Italy & $\begin{array}{l}\text { Udifluventic } \\
\text { Haplustepts }\end{array}$ & Silt loam & 24 & 18 & 21 & 13 & 24 & 3.3 \\
\hline Tetto Frati & Italy & $\begin{array}{l}\text { Oxyaquic } \\
\text { Ustifluvents }\end{array}$ & Silt loam & 27 & 29 & 25 & 7 & 12 & 1.9 \\
\hline Sale & Italy & Unclassified & $\begin{array}{l}\text { Silty clay } \\
\text { loam }\end{array}$ & 10 & 12 & 25 & 16 & 37 & 2.1 \\
\hline Riva & Italy & Unclassified & Silt loam & 11 & 45 & 19 & 5 & 20 & 1.5 \\
\hline Turku & Finland & $\begin{array}{l}\text { Vertic } \\
\text { Eutrudepts }\end{array}$ & Silty clay & 11 & 10 & 16 & 15 & 48 & 3.4 \\
\hline Ritzlhof 4 & Austria & $\begin{array}{l}\text { Typic } \\
\text { Eutrudepts }\end{array}$ & Silt loam & 17 & 36 & 17 & 7 & 23 & 2.4 \\
\hline Keszthely & Hungary & $\begin{array}{l}\text { Typic } \\
\text { Eutrudepts }\end{array}$ & Loam & 38 & 25 & 10 & 5 & 22 & 1.3 \\
\hline Nagyhorvati & Hungary & $\begin{array}{l}\text { Typic } \\
\text { Hapludalfs }\end{array}$ & Loam & 30 & 32 & 13 & 5 & 20 & 1.7 \\
\hline Szentgyorgyvolgy & Hungary & Unclassified & Silt loam & 8 & 41 & 24 & 6 & 21 & 1.4 \\
\hline
\end{tabular}


Table 2. Concentrations of total phosphorus (TP) and the $P$ enrichment ratios (PER) of the silt and clay fractions for 13 European soils.

Soil

$P$ concentration
in silt fraction $\mathbf{m g}$

$$
\mathrm{kg}^{-1} \text { silt }
$$

$P$ concentration in clay fraction $\mathrm{mg}$ $\mathrm{kg}^{-1}$ clay
PER silt

fraction

PER clay

fraction

$\begin{array}{lllll}\text { Rosemaund } & 331 & 1428 & 0.46 & 2.00 \\ \text { Gleadthorpe } & 1688 & 3383 & 1.92 & 3.85 \\ \text { Olcenengo } & 416 & 4732 & 0.64 & 7.26 \\ \text { Villafranca } & 1189 & 3361 & 0.83 & 2.35 \\ \text { Bonavia } & 506 & 2318 & 0.53 & 2.43 \\ \text { Tetto Fratti } & 577 & 4340 & 0.54 & 4.09 \\ \text { Riva } & 497 & 3535 & 0.52 & 3.71 \\ \text { Sale } & 368 & 1852 & 0.24 & 1.21 \\ \text { Turku } & 782 & 2537 & 0.42 & 1.36 \\ \text { Ritzlhof4 } & 788 & 2992 & 0.60 & 2.28 \\ \text { Keszthely } & 286 & 1745 & 0.71 & 4.32 \\ \text { Szent. } & 301 & 3013 & 0.44 & 4.35 \\ \text { Nagyhorvati } & 443 & 2286 & 0.65 & 3.35\end{array}$


Table 3. Runoff, sediment losses, and sediment total phosphorus (TP) concentrations from the 13 study soils for Events 1 and 2 of the rainfall simulations ( $\pm 1 \mathrm{SE}$ of the mean of three replicates).

Event 1

Event 2

\begin{tabular}{|c|c|c|c|c|c|c|}
\hline & & & Sediment & & & \\
\hline & $\begin{array}{c}\text { Runoff } \\
\text { mm }\end{array}$ & $\begin{array}{c}\text { Sediment } \\
\mathrm{g}\end{array}$ & $\begin{array}{c}\text { TP } \\
\mathrm{mg} \mathrm{kg}^{-1}\end{array}$ & $\begin{array}{c}\text { Runoff } \\
\text { mm }\end{array}$ & $\begin{array}{c}\text { Sediment } \\
\mathrm{g}\end{array}$ & $\begin{array}{c}\text { Sediment TP } \\
\mathrm{mg} \mathrm{kg}^{-1}\end{array}$ \\
\hline Rosemaund & $20.6 \pm 4.0$ & $2.7 \pm 1.0$ & $\begin{array}{l}1201 \pm \\
39\end{array}$ & $\begin{array}{l}21.5 \pm \\
3.4\end{array}$ & $2.0 \pm 0.7$ & $1124 \pm 84$ \\
\hline Gleadthorpe & $25.9 \pm 1.0$ & $2.1 \pm 0.1$ & $\begin{array}{l}2884 \pm \\
116\end{array}$ & $\begin{array}{l}25.8 \pm \\
0.9\end{array}$ & $2.0 \pm 0.7$ & $3884 \pm 696$ \\
\hline Olcenengo & $22.7 \pm 1.8$ & $2.5 \pm 0.4$ & $\begin{array}{l}1301 \pm \\
105\end{array}$ & $\begin{array}{l}23.5 \pm \\
0.8\end{array}$ & $2.1 \pm 0.3$ & $1724 \pm 48$ \\
\hline Villafranca & $25.3 \pm 0.4$ & $6.6 \pm 0.6$ & $\begin{array}{l}2390 \pm \\
77\end{array}$ & $\begin{array}{l}22.9 \pm \\
1.9\end{array}$ & $5.5 \pm 0.7$ & 225368 \\
\hline Bonavia & $24.2 \pm 1.5$ & $5.2 \pm 0.4$ & $\begin{array}{l}1027 \pm \\
137\end{array}$ & $\begin{array}{l}22.5 \pm \\
2.2\end{array}$ & $3.1 \pm 0.4$ & $1234 \pm 26$ \\
\hline Tetto Fratti & $25.7 \pm 0.2$ & $16.9 \pm 3.4$ & $\begin{array}{l}1244 \pm \\
267\end{array}$ & $\begin{array}{l}25.2 \pm \\
1.4\end{array}$ & $16.0 \pm 1.4$ & $976 \pm 64$ \\
\hline Riva & $22.5 \pm 1.0$ & $4.7 \pm 0.3$ & $\begin{array}{l}2061 \pm \\
113\end{array}$ & $\begin{array}{l}24.5 \pm \\
0.8\end{array}$ & $4.2 \pm 0.5$ & $1893 \pm 118$ \\
\hline Sale & $13.3 \pm 1.4$ & $3.0 \pm 0.6$ & $\begin{array}{l}1663 \pm \\
123\end{array}$ & $\begin{array}{l}19.4 \pm \\
1.1\end{array}$ & $3.6 \pm 0.3$ & $1871 \pm 119$ \\
\hline Turku & $15.5 \pm 2.0$ & $2.4 \pm 0.5$ & $\begin{array}{l}2061 \pm \\
331\end{array}$ & $\begin{array}{l}15.5 \pm \\
1.8\end{array}$ & $1.9 \pm 0.5$ & $2323 \pm 173$ \\
\hline Ritzlhof4 & $14.3 \pm 0.8$ & $1.7 \pm 0.2$ & $\begin{array}{l}1842 \pm \\
235\end{array}$ & $\begin{array}{l}16.3 \pm \\
2.7\end{array}$ & $1.6 \pm 0.3$ & $2555 \pm 201$ \\
\hline Szent. & $24.6 \pm 1.0$ & $3.4 \pm 0.3$ & $\begin{array}{l}1603 \pm \\
201\end{array}$ & $\begin{array}{l}24.6 \pm \\
1.7\end{array}$ & $2.5 \pm 0.1$ & $1375 \pm 55$ \\
\hline Nagyhorvati & $26.9 \pm 0.3$ & $3.4 \pm 0.4$ & $\begin{array}{l}1544 \pm \\
122\end{array}$ & $\begin{array}{l}26.3 \pm \\
0.2\end{array}$ & $2.6 \pm 0.4$ & $2193 \pm 247$ \\
\hline Keszthely & $22.2 \pm 1.2$ & $2.1 \pm 0.3$ & $\begin{array}{l}1277 \pm \\
70\end{array}$ & $\begin{array}{l}23.0 \pm \\
1.2\end{array}$ & $1.1 \pm 0.2$ & $1368 \pm 74$ \\
\hline
\end{tabular}




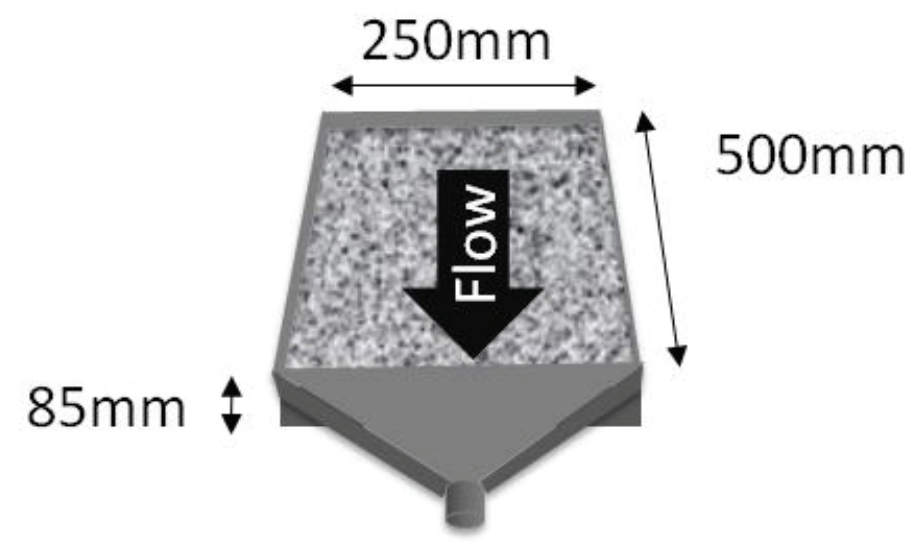

Figure 1 Diagrammatic representation of the soil flume used in the experiments. 
a

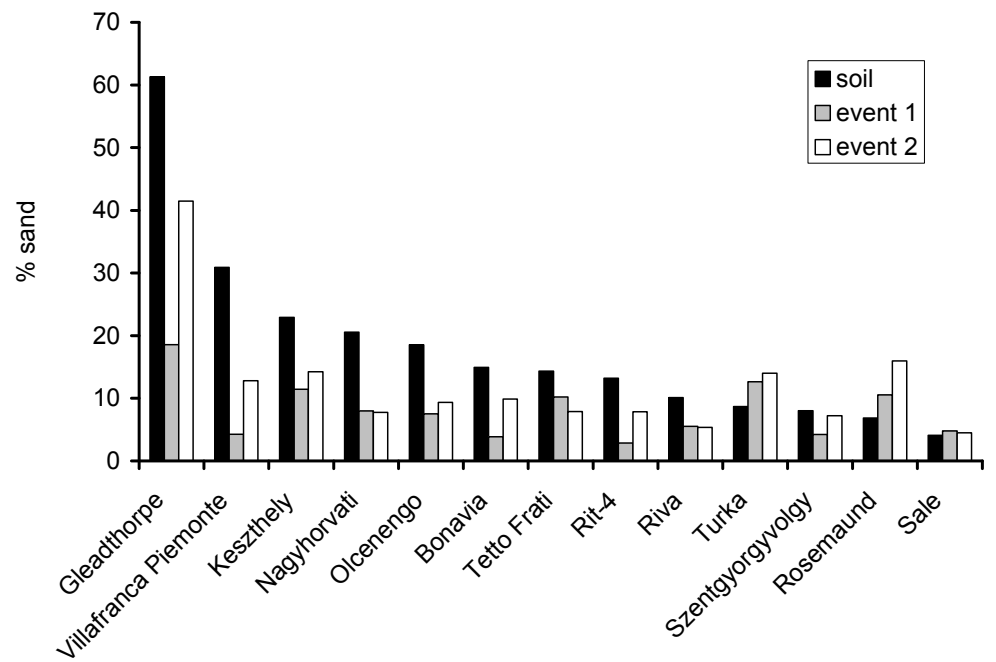

b

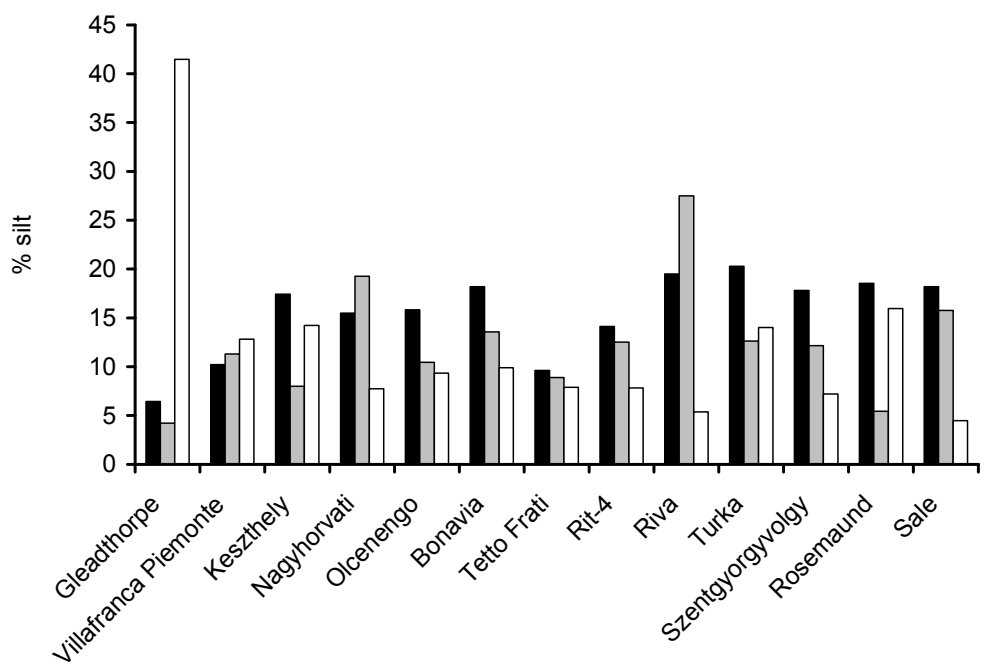

c

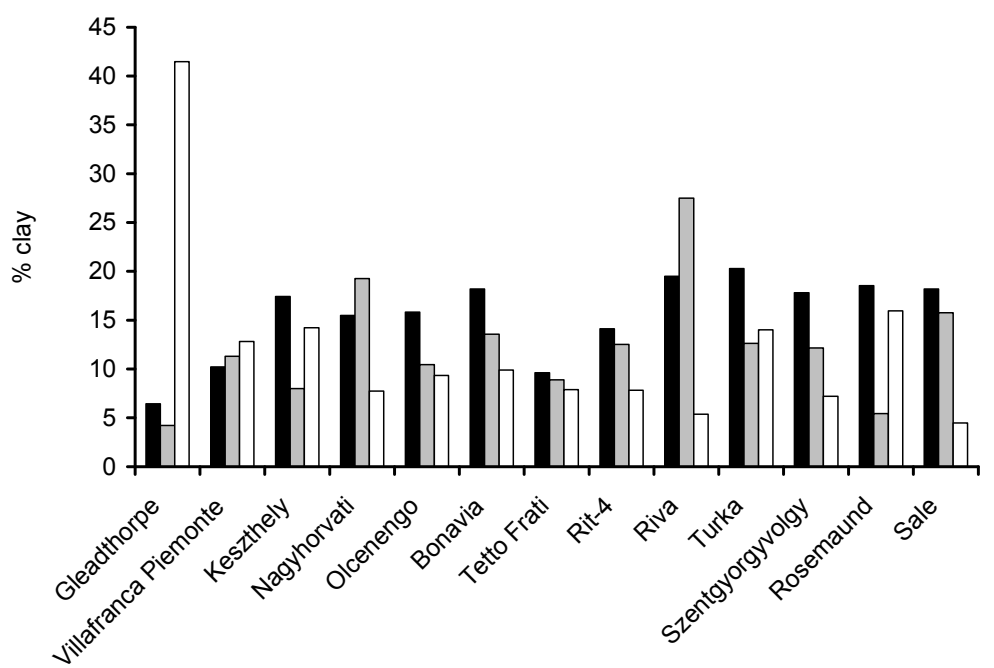

Figure 2. Sand, silt, and clay contents of soil and sediments eroded from Events 1 and 2 . Ranked by soil sand content. 


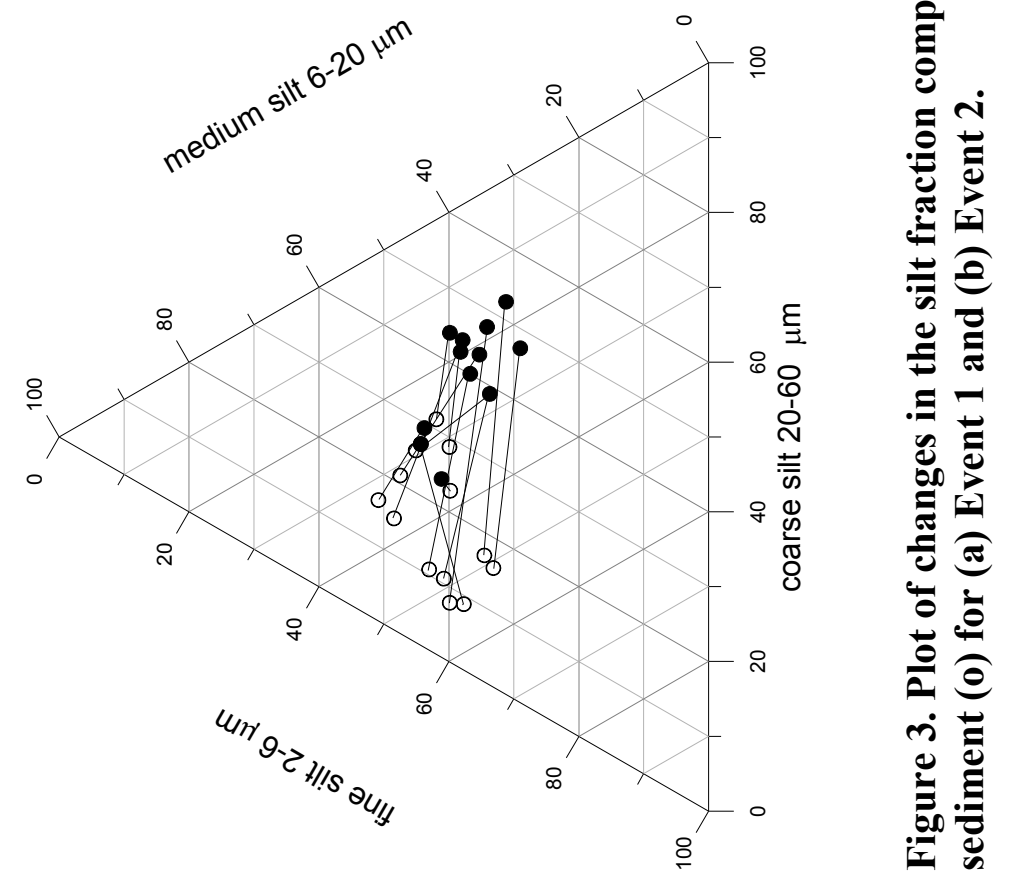




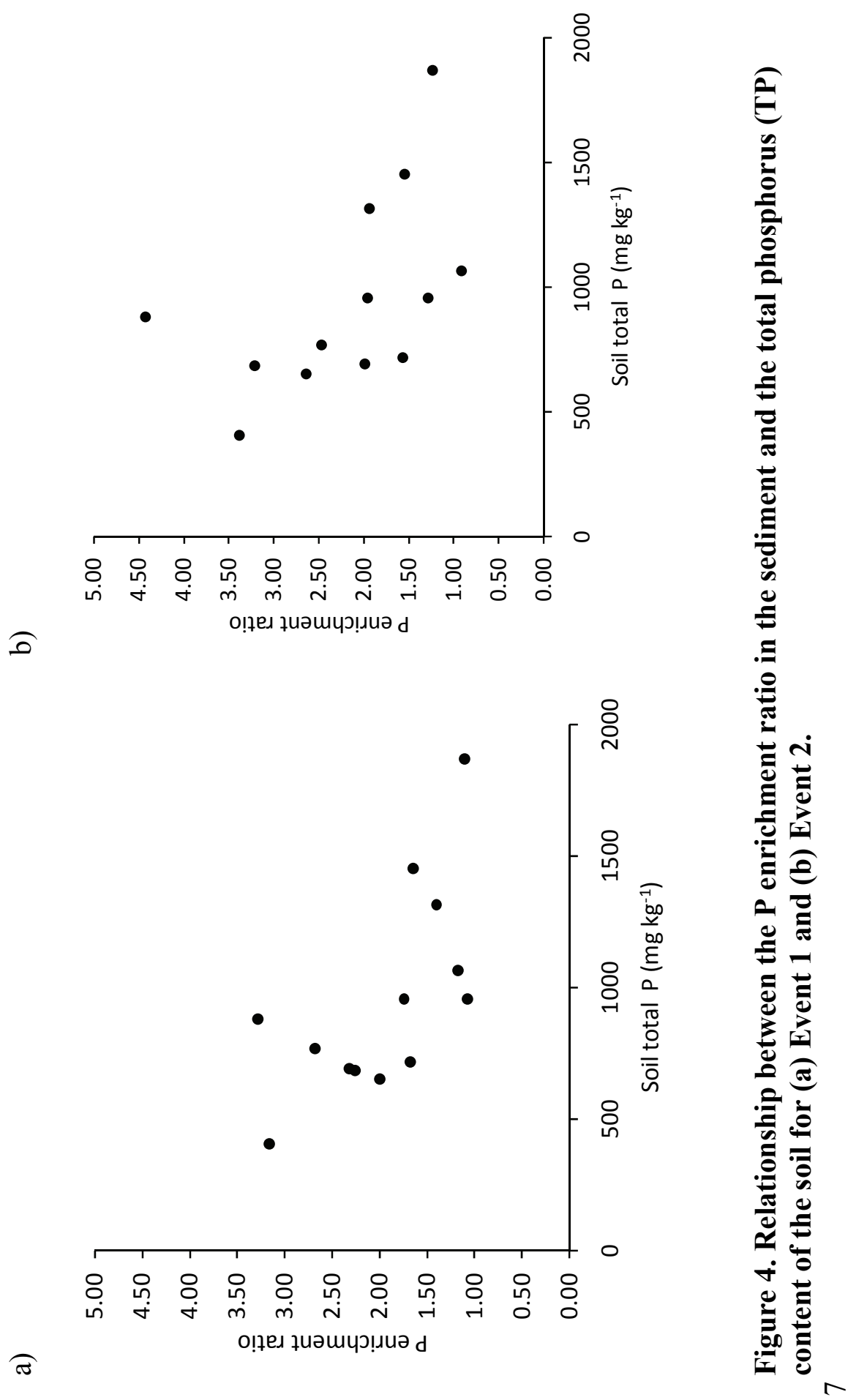




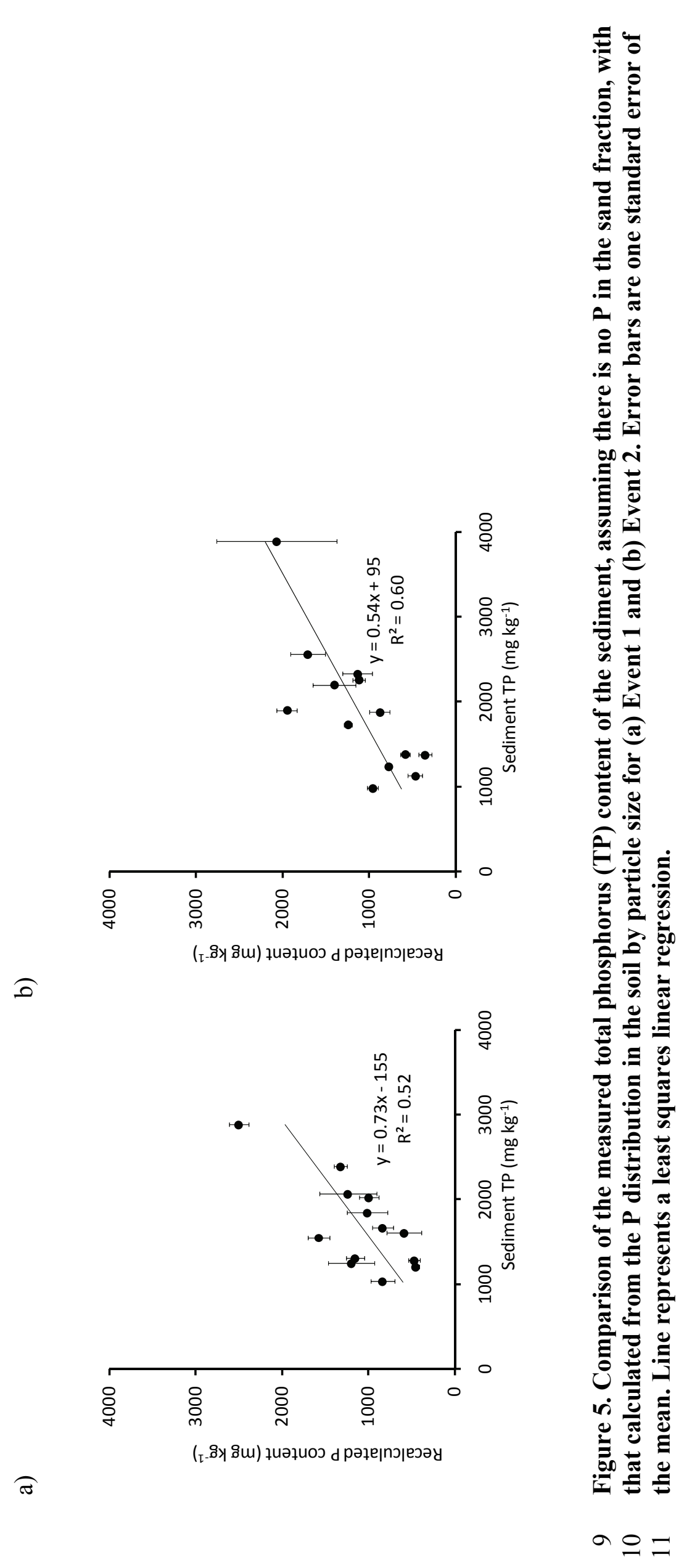

